\title{
ANTICIPATORY ATTACIKS ON SELECTIVE SERVICE CLASSIFICATIONS
}

To the man registered with the Selective Service System, classification is of vital importance. "Classification is the key to selection," and registrants classified I-A are available to be selected for active service. $^{2}$ A registrant may challenge his classification through an administrative procedure. His first option is to request a personal appearance before his local board. ${ }^{3}$ If his plea is rejected here, he may seek review by a state appeal board. ${ }^{4}$ If a member of this board dissents from the majority's action, the registrant may make a final appeal to the President of the United States. ${ }^{5}$ Any further review must occur in the courts.

\section{History of Judicial Review by Anticipatory Attack}

Judicial review of draft board classifications has traditionally been sought in three types of suits : ${ }^{6}$ in a criminal prosecution for failure to obey an induction order, in a petition for habeas corpus brought after accepting induction, and in an anticipatory attack. The latter is a suit brought by a registrant before he has to make the choice of either violating his induction order or accepting induction. Although there are different types of anticipatory attacks, ${ }^{7}$ they have the same object: to secure a judicial determination that the registrant's classification is invalid.

An anticipatory attack is the best form of judicial review from the registrant's point of view. If the registrant chooses to await criminal prosecution, he must risk a prison sentence of up to five years, a fine of up to $\$ 10,000$, or both. ${ }^{8}$ If he chooses a petition for habeas

132 C.F.R. $\$ 1622.1$ (b) (1968).

$2 I d$. $\$ 1622.2$. The prerequisites for the various classifications are described in id. $\S \S 1622.10-.50$.

${ }^{3} I d$. $\$ 1624.1$ (a). The registrant must request the appearance within 30 days of the date on which the board mailed the Notice of Classification. A similar 30 day limit applies to other appeals within the system. See $i d . \$ \$ 1626.2($ a), (c) (1), \& $\$ 1627.3$.

4 Id. $\$ \$ 1626.2(\mathrm{a})$, (c) (1). Note that the registrant may appeal even though he does not have a personal appearance.

5 Id. $\$ 1627.3$. The registrant may request his local board to reopen his classification by submitting facts which, if true, would justify a reclassification; however, reopening is discretionary with the local board. Id. $\$ 1625.2$.

- One attack commonly brought after the registrant has been indicted for violation of his induction order is a petition for habeas corpus before accepting induction. Because it is brought after indictment, it cannot be called a true anticipatory attack.

7 The most common types of anticipatory attacks are suits for an injunction, e.g., Townsend v. Zimmerman, 237 F.2d 376 (6th Cir. 1956), a declaratory judgment, e.g., Meredith v. Carter, 49 F. Supp. 899 (N.D. Ind. 1943), and a common law writ of certiorari, e.g., United States e.r rel. Roman v. Rauch, 253 F. 814 (S.D.N.Y. 1918).

8 See 50 U.S.C. App. \$462(a) (Supp. III, 1968). The common practice in these cases is to offer a registrant found guilty the option of going into the military, instead of serving a prison sentence. This lessens, but does not eliminate, the risk involved in a criminal prosecution. 
corpus, he must undergo induction into the armed forces, with all of its accompanying hardship. ${ }^{9}$ By bringing an anticipatory attack, he avoids these harsh alternatives. However, anticipatory attacks have rarely succeeded. ${ }^{10}$ The most common reason given for dismissing the registrants' suits was that the applicable draft law provided that the Selective Service System's decision on classification was "final," thereby precluding judicial review. ${ }^{11}$

A leading case which granted judicial review in an anticipatory attack is Wolff v. Selective Service Local Board No. 16. ${ }^{12}$ Plaintiffs were undergraduate students who took part in a demonstration held at a local board against the Vietnam War. Because of this action they were declared delinquent, lost their II-S student deferments, ${ }^{13}$ and were reclassified I-A. Without appealing their reclassifications within the Selective Service System or waiting for an order to report for induction, they brought suit for a return of their deferments. The district court dismissed for lack of a justiciable controversy. ${ }^{14}$ The court of appeals reversed, holding that an injunction could issue. ${ }^{15}$ Partly in response to $W$ olff, ${ }^{16}$ Congress amended the draft law in $1967,{ }^{17}$ adding to the previous provision on finality of classification to the following:

No judicial review shall be made of the classification or processing of any registrant by local boards, appeal boards, or the President, except as a defense to a criminal prosecution

9 See note 92 infra and accompanying text.

10 Prior to the Second Circuit's decision in Wolff v. Selective Serv. Local Bd. No. 16, 372 F.2d 817 (1967), so few registrants bringing anticipatory attacks were successful that judicial review by means of anticipatory attack was called an exception to the rule allowing judicial review only as a defense to a criminal prosecution or in a petition for habeas corpus after induction. Compare the successful attacks of Townsend v. Zimmerman, 237 F.2d 376 (6th Cir. 1956) ; United States v. Mancuso, 139 F.2d 90 (3d Cir. 1943); and Tomlinson v. Hershey, 95 F. Supp. 72 (E.D. Pa. 1949); with the unsuccessful attacks in Koch v. Zuieback, 316 F.2d 1 (9th Cir. 1963); Warren v. Abernathy, 198 F.2d 622 (10th Cir. 1952); Local Draft Bd. No. 1 v. Connors, 124 F.2d 388 (9th Cir. 1941); United States ex rel. Beers v. Selective Training \& Serv. Local Bd. No. 1, 50 F. Supp. 39 (W.D. Wis. 1943) ; Allison v. Local Bd. No. 61, 43 F. Supp. 896 (N.D. Cal. 1942); Shimola v. Local Bd. No. 42, 40 F. Supp. 808 (N.D. Ohio 1941); Dick v. Terlin, 37 F. Supp. 836 (S.D.N.Y. 1941); and Brown v. Spelman, 254 F. 215 (E.D.N.Y. 1918). Note, The Selective Service, 76 Yale L.J. 160, $172-73$ n.89 (1966); 81 HARv. L. Rev. 685, 686 \& n.11 (1968).

11 E.g., Meredith v. Carter, 49 F. Supp. 899 (N.D. Ind. 1943) ; Act of Sept. 16, 1940 , ch. $720, \S 10$ (a) (2), 54 Stat. 893.

12372 F.2d 817 (2d Cir. 1967).

13 Both statute and regulation provide for this deferment: 50 U.S.C. App. $\S 456$ (h) (1) (Supp. III, 1968); 32 C.F.R. § 1622.25(a) (1968).

14372 F.2d at 820 .

15 Id.

16 Oestereich v. Selective Serv. System Local Bd. No. 11, 393 U.S. 233, 249 n.10 (1968) (Stewart, J., dissenting). See note 35 infra for a discussion of the effectiveness of such Congressional action.

17 Act of June 30, 1967, Pub. L. No. 90-40, §8(c), 81 Stat. 104, amendivg 50 U.S.C. App. $\$ 460$ (b) (3) (1964) (codified at 50 U.S.C. App. $\$ 460$ (b) (3) (Supp. III, 1968)). 
instituted under section 12 of this title, after the registrant has responded either affirmatively or negatively to an order to report for induction, or for civilian work in the case of a registrant determined to be opposed to participation in war in any form .... ${ }^{18}$

It is clear from the legislative history that this amendment was intended to prevent a flood of anticipatory attacks in federal courts. ${ }^{19}$

\section{OESTEREICH AND GABRIEL}

Two recent decisions radically changed the law governing anticipatory attacks. The question no longer is whether these attacks shall be allowed, but which anticipatory attacks shall be allowed. The cases are Oestereich v. Selective Service System Local Board No. $11^{20}$ and Clark v. Gabriel. ${ }^{21}$

The plaintiff in Oestereich, a divinity student, received from his local board a IV-D classification, an exemption from service granted to "students preparing for the ministry." 22 In an antiwar demonstration on October 16,1967, he and several others returned their Selective Service registration certificates to the government as a sign of protest against the United States' participation in the war in Vietnam. Less than a month after the demonstration, he was declared a

1850 U.S.C. App. $\$ 460$ (b) (3) (Supp. III, 1968).

19 See H.R. REP. No. 267, 90th Cong., 1st Sess. 16 (1967). By this amendment, Congress also intended to eliminate judicial review before the registrant had exhausted his administrative remedies. Id. See Peterson v. Clark, 285 F. Supp. 700, 701 , relief granted, 289 F. Supp. 949 (N.D. Cal. 1968); Kimball v. Selective Serv. Local Bd. No. 15, 283 F. Supp. 606, 607 (S.D.N.Y. 1968).

However, as was conceded in Oestereich by the Solicitor General, habeas corpus post-induction actions were not intended to be eliminated. 393 U.S. at 235.

Nevertheless the law remained unsettled in the lower federal courts. See, e.g., Zigmond v. Selective Serv. Local Bd. No. 16, 396 F.2d 290 (1st Cir.), application for stay of induction denied, 391 U.S. 930 (1968); Moskowitz v. Kindt, 394 F.2d 618 (3d Cir. 1968), cert. dented, 393 U.S. 1014 (1969); Gabriel v. Clark, 287 F. Supp. 369 (N.D. Cal.), rev'd per curiam, 393 U.S. 256 (1968); Petersen v. Clark, 285 F. Supp. 700, relief granted, 289 F. Supp. 949 (N.D. Cal. 1968); Kimball v. Selective Serv. Local Bd. No. 15, 283 F. Supp. 606 (S.D.N.Y. 1968).

20393 U.S. 233 (1968).

21393 U.S. 256 (1968).

22 The exemption is provided for both by statute and by regulation. The statute, 50 U.S.C. App. $\$ 456(\mathrm{~g})(1964)$, states :

[S] tudents preparing for the ministry under the direction of recognized churches or religious organizations, who are satisfactorily pursuing full-time courses of instruction in recognized theological or divinity schools ... shall be exempt from training and service (but not from registration) under this title.

The regulation, 32 C.F.R. $\$ 1622.43$ (a) (3) states:

[Any registrant] [ $w$ ] ho is a student preparing for the ministry under the direction of a recognized church or religious organization and who is satisfactorily pursing a full-time course of instruction in a recognized theological or divinity school [shall be placed in Class IV-D] .... 
delinquent and reclassified I-A by his local board. ${ }^{23}$ He appealed his reclassification, but his I-A status was affirmed unanimously by the appeal board. He was ordered to report for induction on January 24, 1968. Five days before that date, he filed suit in a district court, seeking to enjoin induction. ${ }^{24}$

The district court dismissed the suit, stating, among other reasons, that section 10(b) (3) of the Military Selective Service Act of $1967^{25}$ (limiting judicial review of Selective Service classifications to cases involving criminal prosecutions) deprived the court of jurisdiction. ${ }^{26}$ The Tenth Circuit affirmed per curiam. ${ }^{27}$

The Supreme Court reversed and remanded. In an opinion by Justice Douglas the Court held that section 10(b) (3) cannot be read to preclude pre-induction judicial review in a case in which the board deprived a registrant of his statutory exemption by reclassifying him, under authority of the delinquency regulations of the Selective Service System, for reasons that are unrelated to the merits or conditions of the exemption. The board reclassified plaintiff pursuant to the delinquency regulations which give a board discretionary authority to classify or reclassify any registrant into Class I-A if he fails to perform any duties required of him under Selective Service law. ${ }^{28}$ The asserted failure of duty was twofold: (1) failure to have the registration card in his possession; (2) failure to provide the board with notice of his local status. The Court pointed out that these regulations were promulgated by the Selective Service System, not by Congress, and cannot be used to override a statute which clearly and unequivocally provides that a divinity student shall be exempt from training and service. The Court did not find in the language of the 1967 amendment- " 'prime age group' means the age group . . . from which selections for induction . . . are first to be made after delinquents and volunteers" ${ }^{29}$ - a delegation of authority to deprive a registrant of a statutorily granted exemption on account of delinquency. ${ }^{30}$ Therefore, if a registrant meets the qualifications and conditions set down in the statute, the board has no authority to deprive him of the exemption for reasons unrelated to those qualifications or conditions. Such a

23 The board's action may have been in response to a letter from Selective Service Director Lewis B. Hershey urging local boards to reclassify and induct anti-draft protestors. See Letter from Lt. Gen. Lewis B. Hershey to All Members of the Selective Service System, Oct. 26, 1967, in N.Y. Times, Nov. 9, 1967, $\$ 1$, at 2, cols. 3-5. 24 These facts are taken from Brief for Petitioner at 5-7, Oestereich v. Selective Serv. System Local Bd. No. 11, 393 U.S. 233 (1968).

2550 U.S.C. App. $\$ 460$ (b) (3) (Supp. III, 1968).

26280 F. Supp. 78 (D. Wyo. 1968).

27390 F.2d 100 (10th Cir. 1968).

28 The delinquency regulations are 32 C.F.R. $\$ \S 1642.4$ (a), 1642.12 (1968).

2950 U.S.C. App. $\$ 456$ (h) (1) (Supp. III, 1968) (emphasis added).

30 Justice Douglas's opinion also suggests that even had Congress intended to delegate authority to define the "delinquency" which could deprive a registrant of statutorily granted exemptions, such delegation would be invalid if not accompanied by proper standards to govern the boards' action. 393 U.S. at 237. 
deprivation would be an illegal assumption of power by the board. The Court stated:

We deal with conduct of a local Board that is basically lawless. It is no different in constitutional implications from a case where induction of an ordained minister or other clearly exempt person is ordered (a) to retaliate against the person because of his political views or (b) to bear down on him for his religious views or his racial attitudes or (c) to get him out of town so that the amorous interests of a Board member might be better served. [citation omitted] In such instances, as in the present one, there is no exercise of discretion by a Board in evaluating evidence and in determining whether a claimed exemption is deserved. ${ }^{31}$

Thus, the Court was faced with a situation in which (1) the statute provided that plaintiff shall not be required to serve; $(2)$ the Selective Service System had nevertheless called him to report for induction, and (3) section 10(b)(3) states that no judicial review may be obtained prior to induction. To give effect to section 10 (b) (3) here would mean that plaintiff must either risk the hazards of a criminal prosecution or consent to induction and seek habeas corpus relief in order to defend an exemption given clearly and unconditionally by statute. Finding the two statutory sections taken together to be out of harmony with the Act as an organic whole, ${ }^{32}$ the Court concluded that section 10 (b) (3) cannot be given a literal reading; to do so would be "to construe the Act with unnecessary harshness." 33 Thus, the Court held that judicial review was not precluded by the statute in this situation. ${ }^{34}$

Justice Harlan concurred in the result, reasoning that section 10 (b) (3) was meant to deny judicial review only in cases where a

\section{Id. at $237-38$.}

32 The Court actually said "[e]xamples are legion where literalness in statutory language is out of harmony either with constitutional requirements . . . [citations omitted] or with an Act taken as an organic whole," 393 U.S. at 238, but since no further mention is made of constitutional grounds it is most likely the Court meant the latter.

$33 I d$.

34 An interesting point is raised in the further disposition of the case. The Court reversed and remanded "to the District Court where petitioner must have the opportunity to prove the facts alleged and also to demonstrate that he meets the jurisdictional requirements of 28 U.S.C. \$ 1331." 393 U.S. at 239 . One of the jurisdictional requirements of 28 U.S.C. $\$ 1331$ (a) (1964) is that the matter in controversy exceed the sum or value of $\$ 10,000$, exclusive of interest and costs. It will be difficult for a plaintiff in a draft case to meet this requirement. See Boyd v. Clark, 287 F. Supp. 561, 564 (S.D.N.Y. 1968), aff'd per curriam, 393 U.S. 1112 (1969); id. at 567 (Edelstein, J., dissenting) ; Note, Draft Reclassification for Political DemonstrationsJurisdictional Amonnt in Suits Against Federal Officers, 53 CORNEL L.Q. 916 (1968). If this requirement were insisted upon, it could ban many anticipatory attacks and substantially overrule Oestereich. 
plaintiff seeks to attack a board's findings of fact or mixed law-fact questions, ${ }^{35}$ and not in cases where, as here, the plaintiff attacks the board's regulations as invalid on their face and the procedures as unlawful. To deny judicial review of these questions prior to a deprivation of liberty would "raise serious constitutional problems." 36

Justice Stewart, with whom Justices Brennan and White concurred, dissented on the ground that there is no conflict between plaintiff's exemption and the amendment. Given that the amendment is constitutional, he stated that the Court ought not to disregard it merely because it seems harsh. ${ }^{37}$

The meaning of Oestereich is uncertain. Intertwined in the decision are two separate problems: (1) the proper scope of authority of the Selective Service System, and (2) the degree of departure from this standard which will permit a successful anticipatory attack on a classification in the face of section $10(\mathrm{~b})(3)$. One possible meaning is that the delinquency regulations are invalid when used as a factor in any classification because Congress has not authorized their use (or, alternatively, that if the use was authorized, it is invalid because it is not accompanied by proper standards). There is language in the opinion to this effect. ${ }^{38}$ A second possibility is that the delinquency regulations may not be used to deny a statutory "exemption." However, the use of the word "exemption" ought not carry great weight, and the Court probably intended a third possibility, that the regulations may not be used to deny any clear statutory right. It is the thesis of this

35 This view of the legislative history is not reconcilable with the view of Justice Stewart that $\S 10(\mathrm{~b})(3)$ was meant to prevent a recurrence of the Wolff decision. Compare 393 U.S. at $241-42$ with id. at 247 . Justice Harlan notes that $\$ 10$ (b) (3) was "precipitated" by Wolff, id. at $245 \mathrm{n} .7$, but asserts that the Wolff case, and others, merely involved claims that "the Selective Service boards had maladministered or misapplied the applicable statutes or regulations, and not challenges to the validity of the laws themselves." Id. In fact, Wolff involved allegations (1) that the local board was not authorized to decide that a registrant had violated the criminal provisions of $\$ 12$ (a), 50 U.S.C. App. $\$ 462$ (a) (1965), and thus was a delinquent who could be classified I-A; and (2) that first and sixth amendment rights were being violated. Wolff v. Selective Serv. Local Bd. No. 16, 372 F.2d 817, 820-22 (2d Cir. 1967). Both contentions were sustained. $I d$, at 820 . Acting beyond jurisdiction and infringing constitutional rights both go considerably beyond "maladministration," if that word means simply "making an administrative mistake."

However, Justice Stewart's view also seems in error. It appears that in Wolff, the registrants were engaged in constitutionally protected activities. Id. See Zigmond v. Selective Serv. Bd. No. 11, 396 F.2d 290, 292 (1st Cir.) stay of induction denied, 391 U.S. 930 (1968). Prompt action was held to be necessary to protect these rights. 372 F.2d at 820 . If that is true, to the extent that the case rests on constitutional grounds, the efforts of Congress to overrule it would be in vain; presumably Congress would not attempt to pass unconstitutional legislation.

36393 U.S. at 243 (Harlan, J., concurring). Justice Harlan's constitutional worries do not seem to be shared by the remainder of the Court. See note 32 sipra.

37393 U.S. at 246-49 (Stewart, J., dissenting). Justice Stewart notes that the constitutionality of the $\$ 10$ (b) (3) amendment was not challenged by the Court, and that surrendering a draft card is not a constitutionally protected activity. Id. at 250 n.11, citing United States v. O'Brien, 391 U.S. 367 (1968).

${ }^{33}$ See note 30 supra. 
Comment that this last possibility was the intention of the Court ${ }^{30}$ that anticipatory attack should be granted whenever the delinquency regulations are used to deprive any registrant of a clear, mandatory statutory right.

Gabriel, decided on the same day as Oestereich, throws some light on the problem. In Gabriel, the plaintiff applied to his local board for classification as a conscientious objector. ${ }^{40}$ Most of the evidence on plaintiff's application appeared to concern his civil rights and antiwar activities. ${ }^{41}$ The board rejected his application and classified him I-A. He appealed unsuccessfully in administrative channels. Ordered to report for induction, he brought suit to enjoin his induction and to have the board's action declared improper. The case did not involve the delinquency regulations, and the only issue was whether a registrant could assert by anticipatory attack that a local board erred in its initial classification, or whether he must wait and raise the issue in an action for habeas corpus after induction, ${ }^{42}$ or in a defense to a criminal prosecution. The district court issued a preliminary injunction, holding that a requirement under section 10 (b)(3) that a plaintiff risk criminal penalties in order to obtain judicial review in this case would be an unconstitutional denial of due process of law. ${ }^{43}$

The Supreme Court ${ }^{44}$ reversed per curiam. The Court noted that in this case, unlike Oestereich, the classification made by the board was based solely on findings of fact concerning plaintiff's eligibility for the status of conscientious objector. The opinion stated that

there is no doubt of the board's statutory authority to take action which the appellee challenges, and that action in-

${ }^{30}$ It is also a possibility that the Court merely meant that the combination of factors in this particular case add up to such an outrageous result that in the very clearest of cases the Court would permit anticipatory attack. Cf. Leedom v. Kyne, 358 U.S. 184 (1958) ; Boire v. Greyhound Corp., 376 U.S. 473, 480-81 (1964); Note, 43 TEx. L. REv. 251, 252 (1964). However, there is no suggestion in the language of the opinion that the decision is thus limited. Furthermore, such an approach to the abuses revealed in this case would very likely be ineffective to cure the problem, considering the large number of local boards, and that instances of such abuse are widespread.

4050 U.S.C. App. $\$ 456(j)$ (Supp. III, 1968) defines this exemption. Note that this section sets no standards other than the exercise of discretion by the local board:

Nothing contained in this title shall be construed to require any person to be subject to combatant training and service in the armed forces of the United States who, by reason of religious training and belief, is conscientiously opposed to participation in war in any form. As used in this subsection, the term "religious training and belief" does not include essentially political, sociological, or philosophical views, or a merely personal moral code. Any person claiming exemption from combatant training and service because of such conscientious objections whose claim is sustained by the local board shall, if he is inducted into the armed forces ... be assigned to noncombatant service ....

41 See 393 U.S. at 260-64 (Douglas, J., concurring).

42 See note 19 supra and accompanying text.

43 Gabriel v. Clark, 287 F. Supp. 369 (N.D. Cal. 1968).

44 Direct appeal to the Supreme Court was available under 28 U.S.C. $\$ 1252$ (1965). 
escapably involves a determination of fact and an exercise of judgment. . . . Here the board has exercised its statutory discretion to pass on a particular request for classification, "evaluating evidence and * * * determining whether a claimed exemption is deserved." 45

There are several distinctions from Oestereich suggested in this passage. One is that in Gabriel there is no direct challenge to the power of the board to act. In Oestereich there was no doubt about the fact that the registrant was indeed qualified for the exemption under the terms of the statute; the disputed point was whether, notwithstanding this qualification, the board could take it away from him. However, in Gabriel it is certain that a local board may pass on the merits of a claim to the status of conscientious objector. ${ }^{46}$ But the Court does not stop with that distinction; they go on to suggest a second point, that a determination of fact was involved. The force of this language is not certain. It may refer to the grounds given in Justice Harlan's concurring opinion in Oestereich that review of the action of the board by anticipatory attack is prohibited when there is involved a determination of fact or mixed fact and law. Such distinctions are difficult to make in practice. Moreover, the majority opinion in Oestereich does not refer to such a distinction. More plausible is the third suggestion that the board was involved in an exercise of judgment, of statutory discretion, and that for this reason the action of the board may not be made the subject of anticipatory attack. However, the use of the word "discretion" is unusual. The words of the statute are: "[a]ny person claiming exemption from combatant training and service because of such conscientious objections whose claim is sustained by the local board shall . . . be assigned to noncombatant service . . . " 47 This is not a grant of discretion in the ordinary sense of the word; the board, if it finds the claim sustained, must assign the individual to noncombatant duties-that is, give him a I-A-0 classification. The board may not sustain the claimthat the individual is opposed to war in any form-and then decide for other reasons that the individual should not be given a I-A-0 classification. Nevertheless, if the word discretion is taken to mean a judgment on the existence of a fact (such as the sincerity of a registrant's belief) so subjective that the quality of what is normally thought of as discretion is approached, the use of the word is justified. The distinction from Justice Harlan's theory is that some findings of "fact," for instance, an arbitrary finding that a registrant was not a student, might, under this theory, be subject to anticipatory attack. ${ }^{48}$

45393 U.S. at 258.

46 Id. See note 40 supra. 40 supra.

4750 U.S.C. App. $\$ 456(j)$ (Supp. III, 1968). See the quotation in note

$48 C f$. text accompanying note 31 supra. 
After Oestereich and Gabriel some forms of anticipatory attack are permissible and others are not. Oestereich was in many ways the clearest case for permitting anticipatory attack in the face of the language of section $10(\mathrm{~b})(3)$. Once it has been decided that there is no statutory authority to use the delinquency regulations to deny a statutory right, one can say with some assurance that Congress, had they thought about the problem, would not have meant that the aggrieved registrant may obtain relief only in a defense to a criminal prosecution or a petition for habeas corpus. Gabriel, on the other hand, is a very clear case for not allowing anticipatory attack. Between these two poles is the limit of the Oestereich decision, which this Comment suggests is defined by the presence of an element of discretion in the statutory power granted to the board. This theory must be evaluated in the light of the later actions of federal appellate courts.

\section{Anticipatory Attack Decisions Since OESTEREICH AND GABRIEL}

Since Oestereich and Gabriel, the Supreme Court has decided two cases of anticipatory attack, but neither decision illuminated the question of the extension of the Oestereich doctrine. ${ }^{49}$ Three courts of appeals decisions, however, have squarely faced this question.

The Eighth Circuit in Kolden v. Selective Service Local Board No. $4^{50}$ held that allowance of pre-induction judicial review does not extend to reclassification of deferred graduate students. ${ }^{51}$ The plaintiff, a graduate student at Harvard University, turned in his draft card to the Government on October 16, 1967. On December 1, he was declared delinquent and reclassified I-A pursuant to the Selective Service System's delinquency regulations ${ }^{52}$ for failure to have his registration card in his possession. His appeal was denied, and on February 1, 1968, he was ordered to report for induction. On February 22 , he brought suit to enjoin his induction. The district court denied a motion for temporary injunction on the ground that section $10(\mathrm{~b})(3)$

49 See Moskovitz v. Kindt, 394 F.2d 648 (3d Cir. 1968), cert. denied, 393 U.S. 1014 (1969) ; Boyd v. Clark, 287 F. Supp. 561 (S.D.N.Y. 1968), aff'd per curiam (without reaching the jurisdictional question raised under 28 U.S.C. \$1331), 393 U.S. 1112 (1969). In Moskowitz, the board based its decision on evidence relating to the merits of plaintiff's II-S classification. Boyd was not even a suit for a classification; plaintiffs, all of whom conceded that they were properly classified I-A, brought suit challenging the constitutionality of student deferments. Cf. Muhammed Ali v. Breathitt, 268 F. Supp. 63 (W.D. Ky. 1967).

50406 F.2d 631 (8th Cir. 1969).

51 The statute authorizing graduate student deferments is 50 U.S.C. App. $\S 456$ (h) (2) (Supp. III, 1968):

Except as otherwise provided in this subsection the President is authorized, under such rules and regulations as he may prescribe, to provide for the deferment from training and service in the Armed Forces of any or all categories of persons ... whose activity in graduate study ... is found to be necessary to the maintenance of the national health, safety, or interest .... 52 32 C.F.R. §§ 1642.4(a), 1642.12 (1968). 
at this point barred a review of the merits. The court of appeals granted an injunction pending determination of plaintiff's appeal and deferred decision until the Supreme Court decided Oestereich. Upon consideration of Oestereich and Gabriel, the court held that the district court was correct in denying the injunction, and that the "exception" to section $10(\mathrm{~b})(3)$ afforded Oestereich is not applicable to graduate deferments.

The court reasoned that a graduate deferment is not required by statute but rather is a matter of discretion that rests with local board, and thus is similar to the conscientious objector determination in Gabriel. The conclusion that graduate deferments are discretionary was arrived at by examining the statutory language concerning the graduate student deferment and comparing it with that of the undergraduate deferment in the same section. The operative language of the latter is that "the President shall, under such rules and regulations as he may prescribe, provide for the deferment," ${ }^{3}$ while that of the former is that "the President is authorized, under such rules and regulations as he may prescribe, to provide for the deferment." 54 The court considered the undergraduate classification to be statutorily required, but thought the graduate classification a matter of administrative grace, granted only at the discretion of the local board. Consequently, the Oestereich holding does not extend to graduate deferments.

The Kolden court carefully stated that they were not deciding the case of an undergraduate student deferment, but strongly implied that they would extend Oestereich to undergraduate student deferments. ${ }^{55}$ However, the Second Circuit in Breen v. Selective Service Local Board No. $16^{56}$ reached the opposite conclusion in holding that Oestereich does not extend to undergraduate student deferments.

The plaintiff in Breen was an undergraduate music student at the Berkely School of Music in Boston, and held a II-S deferment. In November 1967, he gave his registration certificate to a clergyman in Boston as a protest of the Vietnam War. On January 9, 1968, his local board declared hin delinquent for failure to have his registration certificate in his possession, and reclassified him I-A. He appealed within the Selective Service System and simultaneously brought suit in the District Court for Connecticut, asking for an injunction, damages, and a declaration that the Board's action was null and void. The district court dismissed the suit on the grounds that section $10(\mathrm{~b})(3)$ deprived the court of jurisdiction. ${ }^{57}$ Subsequently, his administrative appeal failed, and he was ordered to report for induction.

5350 U.S.C. App. $\$ 456$ (h) (1) (Supp. III, 1968).

54 Id. $\$ 456(\mathrm{~h})(2)$.

55406 F.2d at $634,635$. 1969).

56406 F.2d 636 (2d Cir. 1969), cert. granted, 37 U.S.L.W. 3407 (U.S. Apr. 28,

57284 F. Supp. 749 (D. Conn. 1968). 
The court of appeals stayed the order to report and deferred its opinion until Oestereich had been decided. After the decision, the dismissal was affirmed. Judge Friendly distinguished Oestereich on the grounds that Oestereich had a statutory right to an "exemption" which could not be denied him through use of the delinquency regutions, whereas Breen had a mere "deferment" which was granted "under such rules and regulations as [the President] may prescribe." ss Since Executive Order No. $11360^{59}$ authorizes removal of a registrant from II-S classification on a declaration of delinquency, it follows that the board is within its statutory power in doing so. Further, the court did not find the sentence in the statute-" [s] tudent deferments . . . may be substantially restricted or terminated . . . only upon a finding by [the President] that the needs of the Armed Forces require such action" " for reclassification, because Congress specifically recognized in the last sentence of the section that "delinquents and volunteers" are first in induction priority. The court concluded that there is nothing in the statute granting the deferment that would be inconsistent with the use of the delinquency regulations to withdraw it. This being so, the action by the board in reclassifying plaintiff was not unlawful and therefore not subject to pre-induction judicial review.

Judge Feinberg wrote a strong dissent. He pointed out that the statute provides explicitly that the deferment shall continue until the student either graduates, fails to pursue his studies satisfactorily, or reaches his twenty-fourth birthday; and that the deferments shall not be restricted or terminated unless the President finds it necessary for the needs of the Armed Forces. These two factors provide a clear statement of congressional intent, and Judge Feinberg read them as providing no lesser statutory immunity from induction than in Oestercich. He distinguished Gabriel, on the grounds that in Gabriel the registrant's classification necessarily involved an exercise of both fact-finding judgment and discretion by the board, whereas in Breen the classification (as in Oestereich) depends solely on whether the student is in school, and is not conditioned on a finding of fact that must be sustained by the board. Judge Feinberg could find no basis for distinguishing Breen from Oestereich.

The exemption-deferment distinction was also made in Anderson v. Hershey. ${ }^{61}$ In that case nineteen registrants; formerly classified in classes I-A, II-S (undergraduate student), I-Y (registant unable to satisfy physical or mental standards for I-A, I-A-O, or I-O, but who could serve in time of national emergency), and III-A (registrant with child or children or deferred because of hardship to dependents), were

5850 U.S.C. App. $\$ 456(h)$ (1) (Supp. III, 1968).

59 32 Fed. Reg. 9787, 9794 (1967).

6050 U.S.C. App. $\$ 456$ (h) (1) (Supp. III, 1968).

61 No. 18976 (6th Cir., Apr. 11, 1969). 
reclassified under the delinquency regulations. It is not stated in the opinion, but apparently the asserted delinquency was abandonment or mutilation of draft cards. The court discussed specifically the II-S deferments, and then applied the logic a fortiori to the other categories. The court found a difference between an exemption and a deferment, and found it reasonable for the purposes of anticipatory attack: "An exempt person is predetermined to be outside the system; a deferred person is within the system. We deem this a significant line of demarcation." ${ }^{2}$ The court found that there was considerable interest in insuring that those who were deferred, and still within the system, complied with the regulations of the Selective Service, and that, therefore, the use of the delinquency regulations to reclassify a registrant is justified. The court also found Congressional support for this power in the age group language, as well as in the explicit power granted to draft delinquent reserve members. One judge dissented on the grounds that the delinquency regulations were punitive and therefore invalid.

The Breen and Anderson courts erred in placing so great an emphasis on the verbal distinction between an exemption and a deferment. An exemption's importance lies not in its being an "exemption" but in its being a statutory mandate. Since Oestereich's exemption was required by statute, the local board could not withdraw it for reasons unrelated to the merits of the classification. So here, the statute mandates a student deferment for those registrants who meet the requirements:

[T]he President shall, under such rules and regulations as he may prescribe, provide for the deferment from training and service in the Armed Forces of persons satisfactorily pursuing a full-time course of instruction at a college, university, or similar institution of learning and who request such deferment. ${ }^{63}$

If the "rules and regulations" include the Selective Service System's delinquency regulations under which Breen's deferment was withdrawn, then the President has the statutory authority to terminate undergraduate student deferments for any number of reasons. However, Congress has declared the conditions for termination of the student deferment:

A [student] deferment . . . shall continue until such person completes the requirements for his baccalaureate degree, fails to pursue satisfactorily a full-time course of instruction, or attains the twenty-fourth anniversary of the date of his birth, whichever first occurs. Student deferments provided for under this paragraph may be substantially restricted or ter-

62 Id. at 4.

6350 U.S.C. App. $\$ 456($ h) (1) (Supp. III, 1968). 
minated by the President only upon a finding by him that the needs of the Armed Forces require such action. ${ }^{64}$

The clause requiring the President to provide student deferments "under such rules and regulations as he may prescribe" merely authorizes the President to devise a workable system. It does not grant power to apply delinquency regulations, or any other set of conditions, that alter the congressional scheme. The statutory section granting student deferments ends by requiring that registrants whose student deferments have terminated be placed in the "prime age group," defined as that

age group which has been designated by the President as the age group from which selections for induction into the Armed Forces are first to be made after delinquents and volunteers ... 63

Nevertheless, congressional recognition that some persons are to be classed as "delinquents" is not authority for terminating a deferment under conditions other than those set out by Congress. "Delinquents" placed first in the order of call more likely refers to those individuals who have failed entirely to register or have refused to report for a physical, and who are then found on the merits of their own case to be in class I-A.

In contrast to the Breen court, the court in Kolden correctly recognized that the Oestereich holding applies to deferments provided under statutory language, such as "the President shall provide for the deferment" (as in undergraduate deferments), but does not apply to deferments in which "the President is authorized to provide for the deferment" (as in graduate student deferments). An examination of all the statutory language supports this conclusion.

\section{The Statutory Language}

A survey of the statutes providing deferments and exemptions reveals that most of the relevant language is couched in terms of command, such as: "no person shall be inducted"; "no "nerson shall be liable for induction"; "67 "no local board shall order for induction any person." 68 However, the language of a few sections permits discretionary granting of deferments, for example: "any person may be exempted"; ${ }^{69}$ "the President is authorized to provide for the defer-

B4 Id.

$65 I d$.

60 Id. $\$ \$ 454(\mathrm{a}),(\mathrm{c})(3),(\mathrm{i})(1),(\mathrm{k})(8)$ (1964).

67 Id. \$\$ 454(i) (1), (6); 456(b) (1), (2), (3), (4); 456(c) (2) (A) (1964 \& Supp. III, 1968).

68 Id. $\$ \S 455$ (a) (1) (1), (1) (2) (Supp. III, 1968).

$69 I d$. $\$ 456$ (a) (1) (Supp. III, 1968). 
ment"; ${ }^{70}$ and "it is the sense of Congress that the President shall provide for the deferment." ${ }^{71}$ In addition to the generally prevailing language of command, a number of sections set forth specific conditions for the termination of the classifications, ${ }^{72}$ which imply that the classifications are to be terminated only upon the happening of one of those conditions. An example of such a specific section is that section covering undergraduate student deferments, discussed above. ${ }^{73}$ If the statutory language mandates granting a specific classification, a local board should be held to lack statutory authority to reclassify a registrant otherwise qualifying for that classification. Consequently, reclassification contrary to statutory language of mandate would be "basically lawless," 74 and Oestereich should allow preinduction judicial review. However, authorized but non-mandatory classifications and decisions of fact involving statutory discretion, as in Gabriel, would not be subject to anticipatory attack. This is not to say that use of the delinquency regulations to withdraw such classifications is necessarily lawful; but attacks thereon must be limited to habeas corpus and defense of a criminal prosecution. Thus a graduate student deferment, such as in Kolden, which involves an element of discretion would correctly be held to be immune from anticipatory attack.

The distinction drawn in Breen and Anderson between exemptions and deferments is not useful. The statute does not always specify which classifications are exemptions and which are deferments, ${ }^{75}$ and the regulations do not clarify the matter. ${ }^{76}$ Some classifications, other than I-A, appear to be neither. ${ }^{77}$ Moreover, the statutes do not make a rational distinction between deferments and exemptions. Judge Coffin in Anderson argues that the exemption-deferment distinction separates those who are "within" from those who are "without" the system. ${ }^{78}$ Within the class of exemptions are divinity students and ministers, ${ }^{79}$ conscientious objectors, ${ }^{80}$ and students at military colleges (both government owned and private). ${ }^{81}$ Within the class of deferments are undergraduate students, ${ }^{82}$ members of ROTC, ${ }^{83}$ members of

70 Id. \$\$ 454(i) (2) ; 456(h) (2) (1964 \& Supp. III, 1968).

71 Id. $\$ \$ 454$ (i) (3); 456(d) (4) (1964).

72 E.g., id. $\$ \$ 454$ (a), (c) (2), (k) (8); 456 (d) (1), (i) (1), (i) (2); 456(h) (1) (1964 \& Supp. III, 1968).

73 See text accompanying notes 56-65 supra.

74 Oestereich v. Selective Service System Local Bd. No. 11, 393 U.S. 233, 237 (1968).

75 See 50 U.S.C. App. \$ 456 (Supp. III, 1968).

76 See 32 C.F.R. $\$ \$ 1622.2-22.50$ (1968).

77 E.g., 50 U.S.C. App. $\$ 456$ (a) (2) (Supp. III, 1968) (commissioned officers of Public Health Service).

78 No. 18976 at 4.

7950 U.S.C. App. $\$ 456(\mathrm{~g})(1964)$.

so Id. $\$ 456(\mathrm{j})$. The exemption is not from registration or induction, but from combatant duty.

81 Id. $\$ 456$ (a) (1).

82 Id. $\$ 456(\mathrm{~h})(1)$.

${ }^{83}$ Id. $\$ 456$ (d) (1) (1964). 
the National Guard and Reserves, ${ }^{84}$ the Vice-President, state governors, state and federal judges and legislators, ${ }^{85}$ and those with dependency or hardship problems. ${ }^{s b}$ It may be argued that exemptions are granted to registrants because of employment, or some other presumably permanent status, and deferments are granted to registrants with a more transitory status. But this theory does not explain why a federal judge is deferred, while a divinity student is exempted; or why an ROTC member is deferred, while a West Point cadet is exempted.

Furthermore, even if a rational deferment-exemption distinction could be found, it ought not to be determinative of the issue of granting anticipatory attack. There is no reason why a clearly exempted minister should be allowed anticipatory attack upon delinquency reclassification, while a clearly deferred undergraduate student is denied the remedy. Assuming that both have been granted the right by Congress, the fact that one is presumed to be available shortly for service should be irrelevant to his right to contest unlawful action. Judge Coffin suggests that those deferred, and especially undergraduates, should not be prosecuted for infractions of Selective Service law, and that it is preferable to have available the less stringent remedy of reclassification. ${ }^{\$ 7}$ Perhaps this is so. The question is, has Congress made that decision? To provide Congressional support for such use of the delinquency regulations, Judge Coffin cites the "prime age group" passage, ${ }^{s s}$ but the Supreme Court in Oestereich rejected this clause as a source of such power. ${ }^{89}$ Moreover, there is language in Oestereich indicating that any such use of the delinquency regulations was not and cannot be authorized..$^{90}$

\section{Congressional Purpose}

Under pre-Oestereich review procedures, the registrant was apparently limited to review in a defense to a criminal prosecution for disobeying his induction notice or in a habeas corpus proceeding after induction. The burden of undergoing a criminal trial is obvious. The registrant must not only risk the possibility of criminal punishment, ${ }^{91}$

S4 Id. $\$ 456$ (c) (2) (A) (Supp. III, 1968).

$85 I d . \$ 456(\mathrm{f})(1964)$.

S0 Id. $\$ 456(\mathrm{~h})(2)$ (Supp. III, 1968).

ST No. 18976 at 5-6.

88 Id. at 8 citing 50 U.S.C. App. $\$ 456(\mathrm{~h})$ (1) (Supp. III, 1968). See text accompanying note 65 supra.

89 393 U.S. at 237. Judge Coffin suggests this rejection is applicable only to use of the regulations to deny an exemption. See No. 18976 at 8 n.12. But he cites no evidence to show that Congress had made such a distinction.

00393 U.S. at 237. Judge Coffin also cites a provision pertaining to reservists or National Guard members who fail "to serve satisfactorily during [the] period of service." No. 18976 at 8-9, citing 50 U.S.C. App. § 456 (c) (2) (D) (Supp. III, 1968). However, he admits that this provision is equivocal. No. 18976 at 8-9.

91 See U.S.C. App. \$ 462 (Supp. III, 1968). 
but he must also face the notoriety of a criminal trial. The burden of submitting to induction involves both pre- and post-induction dislocation. If employed, he must quit his job; if a student, he must leave school; if a farmer, he must sell his crops. Once inducted, he faces even greater dislocation in the armed forces. ${ }^{92}$

On the other hand, Congress must raise and support armies and must be able, through the Selective Service System, to exercise this power speedily. ${ }^{93}$ In times of all-out war, the survival of the country may depend on the efficiency of the Selective Service; if anticipatory attacks would cause appreciable delay in raising armies, they ought to be discouraged. ${ }^{94}$

Congress spoke to this conflict by enacting section 10 (b) (3). The Court, interpreting this enactment in Oestereich, has said in effect that Congress cannot have meant to bar anticipatory attack when a clear statutory right has been flouted. If Congress meant to confine arguments on the merits of classifications to administrative channels and to allow afterwards only the smallest opportunity for judicial review in order to minimize litigious stalling of induction, the Court's interpretation is consonant with Congressional intent. However, when the Selective Service acts lawlessly, as opposed to erroneously, correction of the error is not best left in their hands. Furthermore, having assumed that a clear statutory right has been violated, little litigation is necessary. If the right is all that clear, the case will be over quickly.

92 This dislocation was classically described by Mr. Justice Murphy, concurring in Estep v. United States:

[T] his remedy [habeas corpus after induction] may be quite illusory in many instances. It requires one first to enter the armed forces and drop every vestige of civil rights. ... The proceeding must be brought in the jurisdiction in which the person is then detained by the military, which may be thousands of miles removed from his home, his friends, his counsel, his local board and the witnesses who can testify in his behalf. Should he overcome all these obstacles and possess enough money to proceed further, he still faces the possibility of being shifted by the military at a moment's notice into another jurisdiction, thus making the proceeding moot. There is little assurance, moreover, that the military will treat his efforts with sympathetic understanding. These practical difficulties may thus destroy whatever efficacy the remedy might otherwise have and cast considerable doubt on the assumption that habeas corpus proceedings necessarily guarantee due process of law to inductees.

327 U.S. 114, 129-30 (1946) (Murphy, J., concurring).

93 Congress's power to raise and support armies is clearly stated in the Constitution. U.S. CoNST. art I, \$ 8 .

That the Selective Service System must be able to exercise Congress's power to raise armies speedily has been repeatedly emphasized in judicial considerations concerning the draft. E.g., United States v. O'Brien, 391 U.S. 367, 381 (1968) ; Falbo v. United States, 320 UU.S. 549, 551-52 (1944). For further discussion, see Reisner, The Conscientions Objector Exemption: Administrative Procedures and Judicial Review, 35 U. CHI. L. Rev. 686, 719 (1968) ; Comment, Faimess and Due Process Under the Selective Service System, 114 U. PA. L. REv. 1014, 1018 (1966).

94 Establishing 2 systems of review of draft classifications, the existing one for wartime and the proposed one for peacetime, might be an effective means of insuring the continued efficiency of the draft system while providing review of classifications whenever possible. The mechanics of such a dual system are suggested in Comment, Fairness and Due Process Under the Selective Service System, supra note 93 at 1018. 
Interpretation of the exemption-deferment line as the limit of Oestereich is not consistent with this view of Congressional intent. Anticipatory attack on lawless conduct which revokes deferments is no more provocative of litigious stalling than an attack on a revoked exemption. The number of suits might increase, but only if the unauthorized practices of the Selective Service continue. ${ }^{95}$ On the other hand, drawing the line at the clear right-discretion distinction implements the Congressional intent. If the allegedly flouted right is not in fact clear, or if it involves elements of discretion, the trial could bog down in substantive arguments, and could more easily be used as a stalling tactic. Use of the delinquency regulations to revoke any classification may be invalid. But limiting anticipatory attack on their use to clear cases will not frustrate Congress's purpose and will provide prompt and adequate relief to those aggrieved by egregious statutory transgressions.

\section{ConCLUSION}

Oestereich will stand as a milestone in the history of judicial review of Selective Service classifications. It marks the farthest extent to date of judicial control over the Selective Service. Before Oestereich, the Supreme Court sanctioned review of classifications only in a defense to a criminal prosecution or in a petition for habeas corpus after induction..$^{96}$ Now there may also be review of classifications in certain anticipatory attacks. Oestereich should be interpreted to encompass only grants of classifications statutorily mandated, but not nonmandatory or discretionary classifications. Limiting pre-induction judicial review to this extent will correct the clearest transgressions of the Selective Service and alleviate obviously aggrieved registrants, without flouting Congressional purpose.

95 A very strong argument against any increase in the number of anticipatory attacks is that such action would open the courts to a flood of registrants suing to enjoin inductions, thereby disrupting the Selective Service System and causing delay in raising armies. To date, the Supreme Court in Oestereich has clearly opened the courts to only a trickle of registrants: those whose exemptions have been withdrawn solely on the authority of the delinquency regulations.

Interpreting Oestereich to allow anticipatory attacks wherever the statute mandated a specific classification undoubtedly would increase the amount of litigation over classifications. A number of registrants who do not now seek judicial review would probably use an anticipatory attack if the route were open to them. However, assuming that this increase in the number of anticipatory attacks is limited to those cases in which there has been clearly unauthorized action, the additional opportunity to litigate is justified. Moreover, a recent statute eliminates any possible advantage to students from litigating beyond their twenty-sixth birthday, normally the cut-off age for liability for the draft, thus reducing the possibility that judicial review may be used as a stalling device. 50 U.S.C. App. $\$ \$ 454(\mathrm{a}), 456(\mathrm{~h})$ (1) (Supp. III, 1968).

Other conditions which could limit availability of anticipatory attacks are suggested in Comment, Judicial Review of Selective Service Action: A Need for Reform, 56 Calti. L. Rev. 448, 463-64 (1968).

96 See, e.g., Witmer v. United States, 348 U.S. 375, 377 (1955). 